\title{
Historical Concepts of Ovarian Dermoid Cysts
}

\section{Onuigbo $\mathrm{W}^{*}$}

Department of Pathology, Medical Foundation and Clinic, Enugu, Nigeria

${ }^{*}$ Corresponding author: Onuigbo W, Department of Pathology, Medical Foundation and Clinic, 8 Nsukka Lane, Enugu, Nigeria 40001, E-mail: wilson.onuigbo@gmail.com

Citation: Onuigbo W (2015) Historical Concepts of Ovarian Dermoid Cysts. J Gynecol Res 1(2): 201. doi: 10.15744/2454-3284.1.201

Received Date: July 06, 2015 Accepted Date: July 29, 2015 Published Date: July 31, 2015

\section{Abstract}

A study of the history of the dermoid cyst of the ovary suggests that the old masters were only conversant with large tumors. The relatively smaller dermoid cyst with its typical greasy matter and hairs only came into recognition during the second half of the $19^{\text {th }}$ century. Therefore, the purpose of this paper is to document how the medical masters of yester years became acquainted with this distinct disease.

Keywords: Dermoid Cyst; Ovary; History; Size; Contents

\section{Introduction}

Because dermoid cysts of the ovary, as in other organs, are characterized by the presence of bone, "cartilage" greasy matter, and hair [1], they must have been observed by the medical masters of yester years. If so, when and how did they document their experiences? This question is what the present paper attempts to review.

\section{Historical Texts}

Documentation by of the Italian anatomist and pathologist, Giovanni Battista Morgagni [2], professor at Padua, led to the original publication of "The Seats and Causes of Disease" in 1761. To that authority, we go for the report on an old woman who had died in the Hospital in the year 1755. Her body, having been brought into the College, he dissected it personally. Now, as he carefully noted, "let us attend to the appearances which were seen in one of the ovaria". Therefore, it is pertinent that he wrote thus: "The ovary was equal in size to a very large walnut, and was made up of white and thick membrane, including water". Assuredly, this description fits the now well known simple ovarian cyst rather than the distinguishingly named "dermoid".

Dermoid elements actually featured as intriguing entities during the $19^{\text {th }}$ century. By that time, there were actually fiery debates on who first operated on the ovary and on whether ovarian operation itself was that of ovariotomy or of ovariectomy [3]. In particular, Lawson Tait [4], Surgeon to the Birmingham and Midland Hospital for Women, viewed the problem as "nomenclature which has become a real element of confusion". As a matter of fact, among his own 208 reported cases, 64 were of ovarian cystoma. As he defined, "By custom, its use was limited to the removal of large cystic tumours of ovarian origin, and it was a long time before solid tumours of the organ were recognised and included in the list of ovariotomies".

Ovariotomies were, as is evident in the above definition, dependant on the very size of the ovary. Indeed, Spencer Wells [5] narrowed his own choice of ovariotomy cases to the "very large" growths. For instance, the ovary removed in 1876 weighed as much as 33 pounds [6]. Incidentally, the qualification was "gigantic ovary" in a famous case which concerned one Mrs. Jane Todd Crawford [7]. Her tumor was removed in the kitchen of Doctor MacDowell on Christmas Day 1809. Interestingly, the patient sang hymns during the 25-minute operation while "the town's people stood guard outside the house in case the surgeon mortally injured his patient".

Patient selection was in those days obviously skewed to size. As was described recently [8], since the mean greatest diameter of dermoids was put at $7.3 \mathrm{~cm}$, while the other benign cysts were in the range of $17.4 \mathrm{~cm}$, this is why the old operation terrains scarcely included dermoids.

Dermoids could not, therefore, have been in consideration when the inimitable Spencer Wells [9] was writing in 1862. As he carefully crafted, if an operation is to be successful, one of the conditions he insisted on was "That the peritoneal cavity should be kept free from fluid". 
Fluid of the murky and greasy type, which is classically associated with dermoid lesions, was at that time clearly not being encountered during the standard operations. Had it been so, that, which Marion Sims [10] cautioned against in 1872, would have been the rule rather than the exception, namely, "Septicaemia is the great outlet of life in ovariotomy".

It is noted that ovariotomy operations carried out in the circumstances of those days did not include dermoids. Therefore, what changed the situation? Probably, this was left to the age of the Meetings held at the Pathological Society of London which was "instituted for the cultivation and promotion of Pathology, by the exhibition and description of specimens, Drawings, Microscopic Preparations, Casts, or Models, of Morbid Parts" [11]. The first issue covered 1846-48. However, by 1859, Nunn [12] communicated an apposite dermoid case. The signal patient, aged 26 years, had undergone an operation. She had never menstruated. From ten years of age, an ovarian tumor had been suspected. The specimen was described beautifully and exactly as follows: "The tumour itself was of a compound character, multilocular, the cysts containing hair, bone, cartilage, and fluids of different colours and densities".

"Densities", no doubt, could not have pointed to a specific diagnosis in keeping with the low level of microscopic diagnosis at that time. Thus, Lionel Beale's Book [13], “The Microscope”, appeared only by 1854. Actually, that book had considerable influence in this field. Thus, Sir William Osler remarked in his obituary notice on Beale that "His early histological studies were of great value, while as practical physicians we must always be thankful to him for the stimulating work which he did in medical microscopy" [14]. Accordingly, microscopy was at the stage in which the puzzling 1859 case was qualified as "cystosarcomatous" and not as "dermoid cyst" [12].

Cyst of the special dermoid type must have awaited the classification of tumors by Rudolph Virchow [15]. Thus, the anonymous reviewer of Virchow's Book of Lectures described one class as follows:

But this manifold variety of forms in the tumour may be still farther increased, and the tumour may come to resemble a collection of organs, a system of the body, as, for instance, the skin. There may be not merely the correlatives of the connective tissue, and of the epidermis, but also of the glands, as of the sweat and sebaceous glands, and even of the hairs, and all the other parts pertaining to the skin. These forms the author designates as teratoid.

Teratoid nomenclature was incidentally appreciated by a 2005 medical historian, Hajdu [16], who wrote on Virchow's life history. As he put it, among the terms that Virchow introduced was "teratomatous (dermoid) cyst of ovary". The parenthesis is noteworthy in that it suggests that it was apparently not part of Virchow's own nomenclature.

Definition of dermoid cyst was sought in the Merriam-Webster's Collegiate Dictionary [17]. Following its practice, it not only defined dermoid cyst as "a cystic tumor often of the ovary that contains skin and skin derivatives (as hair or teeth)" but also supplied the first time that it came into use as 1872. Incidentally, I have not seen the 1872 vintage example. Instead, five years later, during a Meeting of the Pathological Society of London, Griffiths [18] properly presented two cases of dermoid cysts. Surprisingly, he was so meticulous that his preamble concerning the surgical procedure ran thus:

The abdominal section in both cases was performed under carbolic acid spray, the patients being under the influence of bichloride of methylene, and subsequently treated antiseptically after the plan of Professor Lister. In both cases also carbolised catgut was employed to secure the pedicle and to stitch the wound in the abdominal wall.

Wall and other elements were thereafter fully described as follows:

In general appearance it may be said to have a faint resemblance to the body of a small foetus. On what may be taken for the head a lock of brown hair is grown, about 6 inches long, and having attached to its free end a lump of matted hair (chignon-like) of the same colour. On either side, and near the head, are observed two osseous and cartilaginous projections in place of upper limbs. This rudo-cystic growth consists chiefly of fibrous, adipose, osseous, and cartilaginous tissues. The fluid contained in the cyst resembled dirty porter in appearance, and had suspended in it some lumps of whitish sebaceous substance. This sebaceous substance was a source of some trouble at the operation. When a small trocar was thrust into the cyst its point came in contact with some of it which plugged up the tube. On withdrawing the instrument the fluid spurted out with considerable force, but, thanks to the excellent help I had, none escaped into the peritoneal cavity.

Cavity contents were also characterized in a manifestly memorable manner in the second case. These contents exhibited themselves in a 21-year-old married woman, the descriptions being terse:

The tumor is a unilocular cyst, having attached to its wall the fimbriated extremity of the Fallopian tube. The cyst is imperfectly divided by several irregular septa, and it contains a lump of light brown hair, matted together with some sebaceous and greasy substance, which is connected with some other hair attached to the side of the cyst. In the centre of the hairy portion of the cyst wall is observed an alveolar process, about three quarters of an inch long, covered with perfect looking gums and possessing two deciduous teeth.

Teeth were incisively described above. No less an accurate description came from Stephen Paget [19], whose review of organ selectivity in breast cancer metastasis in 1889 became a masterpiece. However, he had but few data on dermoid cysts. Thus, on analyzing the celebrated Middlesex Hospital Reports which contained only "very carefully recorded" necropsies, he found that there were in 243 cases only 3 dermoid ovarian cysts as against 27 uterine fibroids. Moreover, when he documented the same number of necropsies as regards cancer of the uterus, there was no dermoid. 


\section{Conclusion}

Dermoid cysts have, nowadays, gained such ascendancy that the current literature is replete with articles. Thus, a review [20] covered fields as diverse as superinfection, obstructive pregnancy, malignancy and the enigmatic struma ovarii. Incidentally, interest even centered on a selective study of "unilateral teratoma no larger than $10 \mathrm{~cm}$ " [21]. It decided delicately that laparoscopy has the same efficacy as laparotomy. Undoubtedly, ovarian dermoid cysts are characteristic entities that fully engage present practitioners. To conclude, it is well to be reminded about how the medical men of yester years ultimately appreciated it themselves.

\section{References}

1. Rosai J (1996) Rosai and Ackerman's Surgical Pathology ( $8^{\text {th }}$ Ed), Elsevier Health Sciences Kidlington, Oxford, United Kingdom.

2. Morgagni JB (1769) The Seats and Causes of Disease Investigated by Anatomy, Containing a Great Variety of Dissections with Remarks ( ${ }^{\text {rd }}$ Ed) London.

3. Jackson JD (1874) The first ovariotomy. Br Med J 1: 467.

4. Tait L (1883) An account of two hundred and eight consecutive cases of abdominal section performed between Nov. $1^{\text {st }} 1881$, and December $31^{\text {st }}$, 1882. Br Med J 1: $300-4$.

5. Wells S (1862) Ovarian tumours removed by ovariotomy. Trans Pathol Soc Lond 13: 172-3.

6. Kimball G (1876) Extirpation of the uterus in connection with ovariotomy, Followed by Recovery. Boston Med Surg J 95: 250-2.

7. Hill GJ (1979) Historic milestones in cancer surgery. Semin Oncol 6: 409-27.

8. Katsube Y, Berg JW, Silverberg SG (1982) Epidemiologic pathology of ovarian tumors: A histopathologic review of primary ovarian neoplasms diagnosed in the Denver Standard Metropolitan Statistical Area, 1 July-3 December 1969 and 1 July-31 December 1979. Int J Gynecol Pathol 1: 3-16.

9. Wells TS (1863) On the history and progress of ovariotomy in Great Britain, with observations founded on personal experience of the operation in fifty cases. Med Chir Trans 46: 33-55.

10. Sims JM (1873) On ovariotomy. Am J Med Sc 129: 282-3.

11. Anonymous (1846-48) Bye-laws and regulations. Trans Pathol Sos London 1: 15.

12. Nunn TW (1859) Two specimens of ovarian disease. Trans Pathol Soc Lond 9: 207-8.

13. Beale S L (1854) The Microscope and Its Application to Clinical Medicine. London: Samuel Highley 163.

14. Forster WD (1958) Lionel Smith Beale (1828-1906) and the beginning of clinical pathology. Med Hist 2: 269-73.

15. E.T.C. Morbid tumours. Thirty lectures delivered during the winter term of 1862-63 at the University of Berlin. Am J Med Sci $186549: 164-78$.

16. Hajdu SI. (2005) Rudolph Virchow, Pathologist, armed revolutionist, politician and anthropologist. Ann Clin Lab Sci 35: 203-5.

17. Merriam-Webster's Collegiate Dictionary (2007) (11 th Ed) Springfield, US 336.

18. Griffiths TD (1871) Two dermoid ovarian tumours. Trans Pathol Soc Lond 28: 196-200.

19. Paget S (1889) The distribution of secondary growths in cancer of the breast. Lancet 133: 571-3.

20. Comerci JT Jr, Licciardi F, Bergh PA, Gregori C, Breen JL. (1994) Mature cystic teratoma: a clinicopathologic evaluation of 517 cases and review of the literature. Obstet Gynecol 84: 22-8.

21. Mais V, Ajossa S, Mallarini G, Guerriero S, Oggiano MP, et al. (2003) No recurrences of mature teratomas after laparoscopic cystectomy. Br J Obstet Gynecol 110: 624-6. 